\title{
INFLUENCE OF MACHINING STRATEGIES AND TECHNOLOGICAL HISTORY OF SEMI-FINISHED PRODUCT ON THE DEFORMATION OF THIN-WALL ELEMENTS AFTER MILLING
}

\author{
Magdalena Zawada-Michałowska' ${ }^{1}$, Józef Kuczmaszewski' ${ }^{1}$ Paweł Pieśko ${ }^{1}$, Waldemar Łogin² \\ 1 Department of Production Engineering, Faculty of Mechanical Engineering, Lublin University of Technology, \\ Nadbystrzycka 36, 20-618 Lublin, Poland, e-mail: j.kuczmaszewski@pollub.pl, p.piesko@pollub.pl, \\ m.michalowska@pollub.pl \\ 2 Polskie Zakłady Lotnicze Sp. z o.o. A Sikorsky Company, Wojska Polskiego 3, 39-300 Mielec, Poland, e-mail: \\ waldemar.login@Imco.com
}

Received: 2017.05.15

Accepted: 2017.08.01

Published: 2017.09.03

\begin{abstract}
The paper presents an analysis of the influence of machining strategy and the technological history of semi-finished product on the deformation of thin-walled elements made of aluminium alloy EN-AW 2024 after milling. As a part of this research work, five machining strategies are analysed. Additionally, the rolling direction of the plate (longitudinal and transversal) is taken into account as a technological history. During the research, the focus is set on the effects of the machining strategies i.e. HPC, HSM and conventional machining as well as their combinations on the post-machining stresses and deformations. Each of these strategies has a different range of technological parameters, which results in differences in machining efficiency and introduces post-machining stresses to the surface layer of the workpiece that vary in values and nature (i.e. compressive stresses or tensile stresses). The conducted study shows that larger deformations were obtained for transversal rolling direction in each analyzed case. The lowest deformation both for transversal and longitudinal rolling direction were achieved for the HSM and CM strategy.
\end{abstract}

Keywords: machining strategies, technological history, thin-walled elements, deformation.

\section{INTRODUCTION}

HPC (High Performance Cutting), HSC (High Speed Cutting), and their derivatives have been increasingly popular in machining processes, especially those applied in aerospace and automotive industries. The advantages, aside from the obvious increase in machining production efficiency, include feasibility of hard machining (i.e. machining of hardened materials) $[6,17-20]$, which is applied mainly for processing of dies, moulds, or blanking tools $[9,14,17]$. Both methods eliminate the need for time-consuming and expen- sive electrical discharge machining (EDM), which improves energy saving and machining parts accuracy as well as surface quality [8, $22,24]$. Neither HPC or HSC requires cooling lubricants (dry machining), and if any is required, it is at minimum flow rates (quasi dry machining), which significantly reduces the production costs (where the purchase, storage and utilization of cooling lubricants can be between $14 \%$ and $17 \%$ of the total manufacturing cost) $[8,13]$. Note, however, that there is no defined boundary between HSC, HPC and conventional cutting, since the qualification of machining into any of these three classes de- 
pends on the strong interdependence between the processing conditions (including cutting forces and temperatures) and the workpiece material properties.

HSC can be generally considered as a finish machining process, where very high rotational speed of the cutting tool provides cutting speeds and feed rate values several times higher than in conventional machining at much lower machined layer cross-section values [20]. By its original definition, HSC was deemed to be 5 to 10 times faster (depending on the workpiece material) than conventional machining speed values $[1,2,6$, 18-21]. One of the proposed definitions of HSC introduces the so-called limit cutting speed $\mathrm{v}_{\mathrm{cl}}$, above which the high cutting speed range begins. Its value is established based on an analysis of the cutting forces that vary as the cutting speed is increased; some researchers [1, 2, 5] propose that HSC starts when the increase of the cutting speed causes reducing the cutting forces. Other practices $[3,4,20]$ define the limit cutting speed as the cutting speed up to which the cutting forces are significantly reduced.

Taking into consideration the machine parameters, HSC is determined by the machine tool dynamics and the spindle rotational speed [15]. An important aspect of this type of machining on CNC machine is the use of control with the look-ahead function (displacement forecasting in advance) $[15,20]$.

Given this information, a conclusion is due that a comprehensive examination of numerous factors that can be qualified into four categories (Fig. 1) is required to obtain $\mathrm{HSC}[8,10,15,17-21]$ :
- the workpiece - the type and grade of material, geometry and fixture method of workpiece;

- the cutting tool - the selection of geometry, material and coatings to ensure stable performance and sufficient life of the cutting tool [11, 12];

- the machining tool - which should feature a high rigidity, spindle speed and power output, sufficient machining dynamics and a control system that is capable of look-ahead forecasting of displacement;

- manufacturing process conditions - the use of machining method, the selection of a proper strategy, application of modern CAM software, cooling type selection, etc.

The main advantages of HSC are higher efficiency (by an average of $30 \%$ ), high quality of machined surfaces, opportunity of cutting of hardened materials, 30\% lower cutting forces, improved processing stability, minimized vibration levels, lower thermal loading of the tool and the workpiece, and reduced burring $[8,10,17-21,23]$.

Main applications of HSC:

- high-performance processing of complex thin-wall aluminium structures mainly for the aerospace industry - it is viable by minimised cutting forces, vibration levels, and thermal deformation level;

- end-to-end finish processing of semi-finished products heat-treated to their final hardness values - machining of moulds and dies at efficiency and quality levels much higher than possible with EDM; obtaining of superior

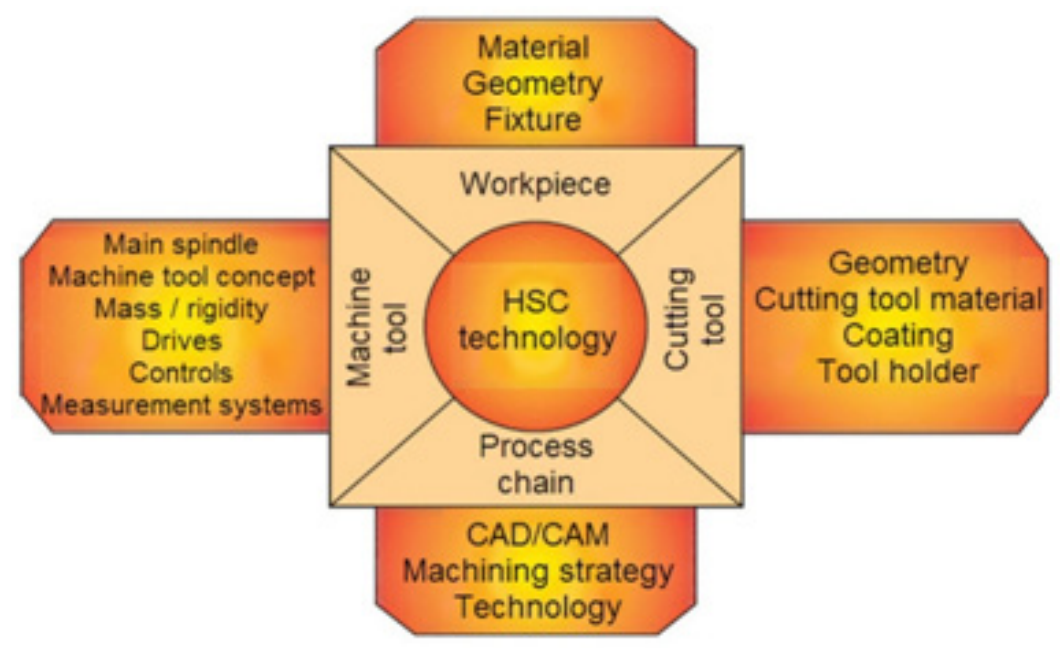

Fig. 1. HSM determinants [8] 


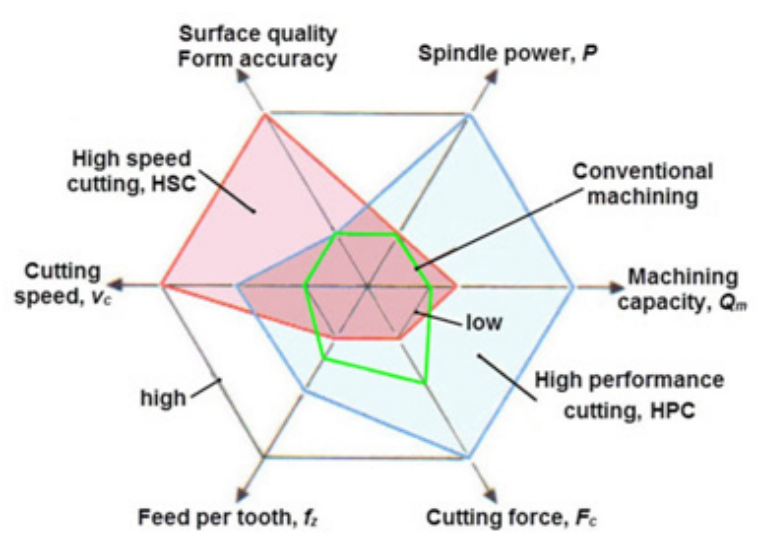

Fig. 2. Comparison of conventional machining to HSC and HPC $[6,18,20]$

surface quality and shape accuracy reduces the need for finish machining by grinding or polishing;

- machining of titanium and nickel alloys, as well as heat-resistant steel grades, mainly for the aerospace industry.

In contrast to HSC, HPC can be qualified as roughing with the major objective of increasing the efficiency. This is achieved by applying unconventionally high cutting speeds, high machined layer cross-section values and high feeds $[6,18,20]$. Higher cutting depth and width values increase contact angle of tool and workpiece, which results in strong heating of the blades and makes it more challenging to cool them down; as a consequence, the tool is subject to thermal overload. This, in turn, requires cutting speeds lower than viable with $\operatorname{HSC}[6,18,20]$. Moreover, increasing the feed rate and the machined layer dimensions results in increased cutting forces. The disadvantages of HPC include processing instability in machining of deep thin-wall pockets with tools at critical diameter to length ratios [5]. This is why HPC is mainly used for roughing and forming [21].

Considering the properties of HSC and HPC explained above, HSC can be defined as machining at high cutting speeds and low machined layer cross-section values. HPC uses moderate cutting speeds at much higher axial and radial traverse (i.e. cutting depth and width values) and feed per tooth values (Fig. 2).

HSC, on account of its high geometric accuracy and machined surface quality at low cutting forces and high machining stability, is preferred for processing complex $3 \mathrm{D}$ geometric features and thin-wall pockets with low bottom section thickness values. HPC, as it stands for high performance machining with low accuracy, is mainly used for processing of 2D parts with simple geometric features or with simple forming movements [19].

One of the applications of HSC and HPC mentioned before is machining of thin-wall pockets, which are defined as structural components in the aerospace industry. The semifinished products used to manufacture these types of parts are rolled plates made of socalled aerospace aluminium alloys grades, characterized by very good strength properties. Rolling is a plastic working process, which results in the anisotropy of the semi-finished products. Hence, the structural and mechanical properties of material vary with the direction relative to the rolling direction $[7,25,26]$.

The semi-finished products as rolled plates made of aluminium alloys, which have anisotropic mechanical properties, and the application of different machining strategies (High Performance Cutting, High Speed Cutting and conventional milling), most likely results in different states of stresses in the surface layer of machined elements. This gives various forms and values of deformation.

This paper describes an attempt at evaluating the influence of the rolling direction and used machining strategy on the deformation forms and values in thin-wall elements made of a specific aluminium alloy grade.

Table 1. EN AW-2024 chemical composition and selected mechanical properties [16]

\begin{tabular}{|c|c|c|c|c|c|c|c|c|c|c|c|}
\hline Mark & Mark & Featur & \multicolumn{9}{|c|}{ Chemical composition [\%] } \\
\hline ref. PN-EN 573-3 & \multicolumn{2}{|c|}{ ref. PN-76/88026 } & $\mathrm{Si}$ & $\mathrm{Fe}$ & $\mathrm{Mg}$ & $\mathrm{Cu}$ & $\mathrm{Mn}$ & $\mathrm{Zn}$ & $\mathrm{Cr}$ & $\begin{array}{c}\mathrm{Zr}+ \\
\mathrm{Ti}\end{array}$ & Other \\
\hline EN AW-AICu4Mg1 & AlCu4Mg1 & PA7 & $\leq 0.5$ & $\leq 0.5$ & 1.5 & 4.2 & 0.6 & $\leq 0.25$ & $\leq 0.1$ & $\leq 0.2$ & $\leq 0.15$ \\
\hline \multicolumn{12}{|c|}{ Mechanical properties } \\
\hline $\mathrm{E}[\mathrm{GPa}]$ & \multicolumn{2}{|c|}{$R_{p 0,1}[\mathrm{MPa}]$} & \multicolumn{2}{|c|}{$\mathrm{R}_{\mathrm{t} 0,5}[\mathrm{MPa}]$} & \multicolumn{2}{|c|}{$\mathrm{R}_{\mathrm{m}}[\mathrm{MPa}]$} & \multicolumn{3}{|c|}{$A_{g}[\%]$} & \multicolumn{2}{|c|}{$\mathrm{A}_{5,65}[\%]$} \\
\hline 78 & \multicolumn{2}{|l|}{347} & \multicolumn{2}{|l|}{342} & \multicolumn{2}{|c|}{423} & \multicolumn{3}{|c|}{2} & \multicolumn{2}{|c|}{4} \\
\hline
\end{tabular}


Table 2. Technological parameter values for specific machining strategies

\begin{tabular}{|c|c|c|c|c|c|c|c|c|}
\hline \multirow{3}{*}{ Technological parameters } & \multicolumn{8}{|c|}{ Strategy } \\
\hline & \multirow{2}{*}{ HPC } & \multicolumn{2}{|c|}{$\mathrm{HPC}+\mathrm{CM}$} & \multicolumn{2}{|c|}{$\mathrm{HPC}+\mathrm{HSM}$} & \multirow{2}{*}{ HSM } & \multicolumn{2}{|c|}{$\mathrm{HSM}+\mathrm{CM}$} \\
\hline & & HPC & $\mathrm{CM}$ & HPC & HSM & & HSM & $\mathrm{CM}$ \\
\hline Depth of cut $a_{p}[\mathrm{~mm}]$ & 4.5 & 4.5 & 0.4 & 4.5 & 0.4 & $1 ; 0.4^{*}$ & 1 & 0.4 \\
\hline Milling width $a_{\mathrm{e}}[\mathrm{mm}]$ & 18.75 & 18.75 & 12 & 18.75 & 12 & 12 & 12 & 12 \\
\hline Cutting speed $v_{c}[\mathrm{~m} / \mathrm{min}]$ & 1000 & 1000 & 200 & 1000 & 1200 & 1200 & 1200 & 200 \\
\hline Feed per tooth $\mathrm{f}_{\mathrm{z}}[\mathrm{mm} /$ tooth $]$ & 0.1 & 0.1 & 0.02 & 0.1 & 0.02 & 0.02 & 0.02 & 0.02 \\
\hline Rotational speed n [rpm] & 12732 & 12732 & 3979 & 12732 & 23873 & 23873 & 2873 & 3979 \\
\hline Feed rate $v_{f}[\mathrm{~mm} / \mathrm{min}]$ & 3820 & 3820 & 239 & 3820 & 1432 & 1432 & 1432 & 239 \\
\hline No. of passes i [-] & 2 & 2 & 1 & 2 & 1 & $9 ; 1^{*}$ & 9 & 1 \\
\hline
\end{tabular}

\section{METHODOLOGY}

The test samples were fabricated from rolled EN AW-2024 aluminium alloy plate. The chemical composition and selected mechanical properties of the alloy are shown in Table 1. The machining were carried out with an Avia VMC 800 HS 3-axis milling centre.

These thin-wall elements were carried out with two cutting tool types: a Kennametal indexable end mill (25A03R044B25SED14) with uncoated carbide inserts (EDCT140416PDFRLDJ) for HPC and a Sandvik monolithic carbide end mill without a protective coating (R216.3316040-AC32U H10F) for HSM and conventional machining.

Five milling strategies were used in the tests:

- High Performance Cutting (HPC),

- High Performance Cutting with conventional finish machining (HPC $+\mathrm{CM})$,

- High Speed Machining (HSM),
- High Performance Cutting + High Speed Machining (HPC + HSM),

- High Speed Machining with conventional finish machining ( $\mathrm{HSM}+\mathrm{CM})$.

Table 2 lists the applied technological parameters for each of the milling strategy investigated. The overall dimensions of the test samples cut from the rolled plate and before the machining are $210 \times 45 \times 10 \mathrm{~mm}$. They were milled with various strategies to obtain a $160 \mathrm{~mm}$ long relief along the entire width with a $1 \mathrm{~mm}$ thick bottom (Fig. 3).

The assumed effect of technological history was the rolling direction. The test samples were performed in two directions:

- longitudinal: the rolling direction was parallel to the sample long edge and to the direction of feed,

- transversal: the rolling direction was perpendicular to the sample long edge and to the direction of feed.

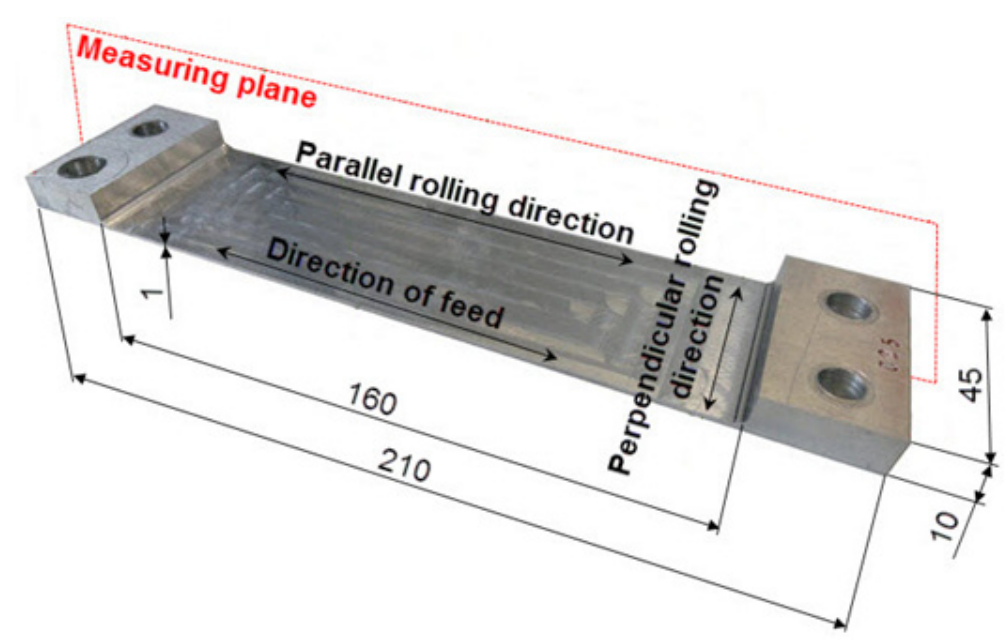

Fig. 3. Test sample after machining 


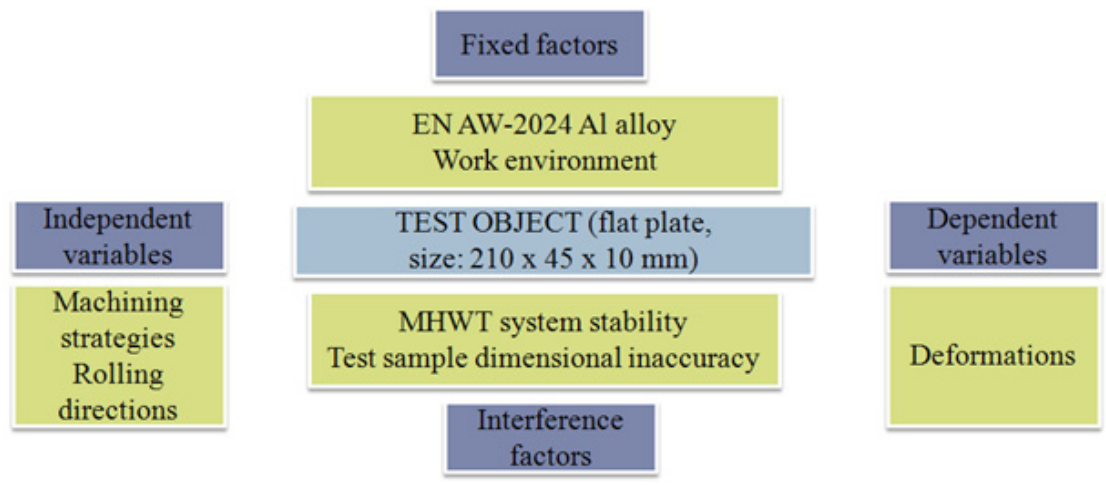

Fig. 4. Research plan

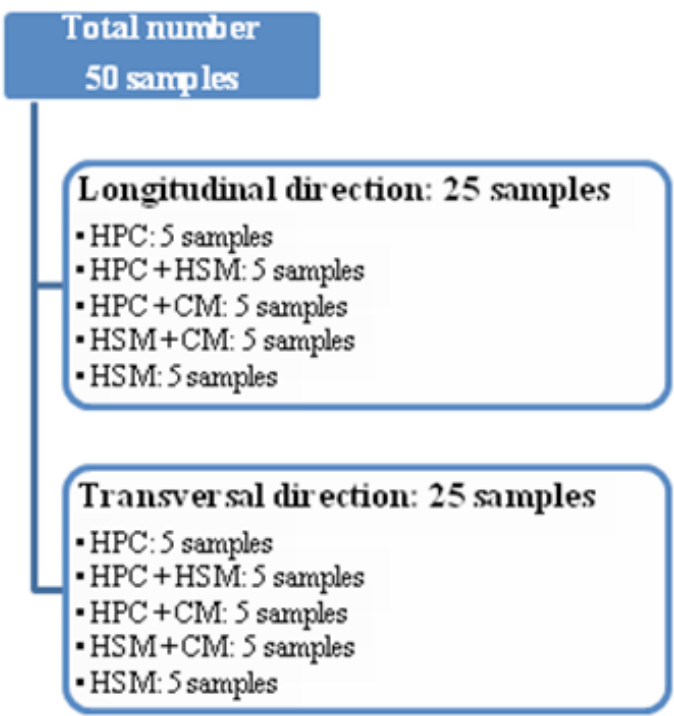

Fig. 5. Diagram of tested variables

Figure 3 also shows a view of test sample after machining with the marked dependence between the rolling directions and the feed direction.
The test sample deformations were measured directly after removal of a special fixture with a Sylvac CL44 digital sensor attached with a magnetic holder to the work head of the Avia VMC 800 HS milling centre.

The measuring plane across which the deformations were measured is presented in Figure 3 by red colour. The measuring section of the test samples was $1=160 \mathrm{~mm}$.

The research plan is shown in Figure 4. The independent variables were the machining strategies and the rolling direction, and the dependent variables were the deformations. The fixed factors were the EN AW-2024 aluminium alloy and the work environment, and the interferences were the stability of the MHWT system (Machine Holder - Workpiece - Tool) and the dimensional inaccuracy of the test samples.

The experimental testing included a total of fifty test samples. Five test samples were machined with each of the five machining strategies, with a total number of twenty five samples per rolling direction (Figure 5).

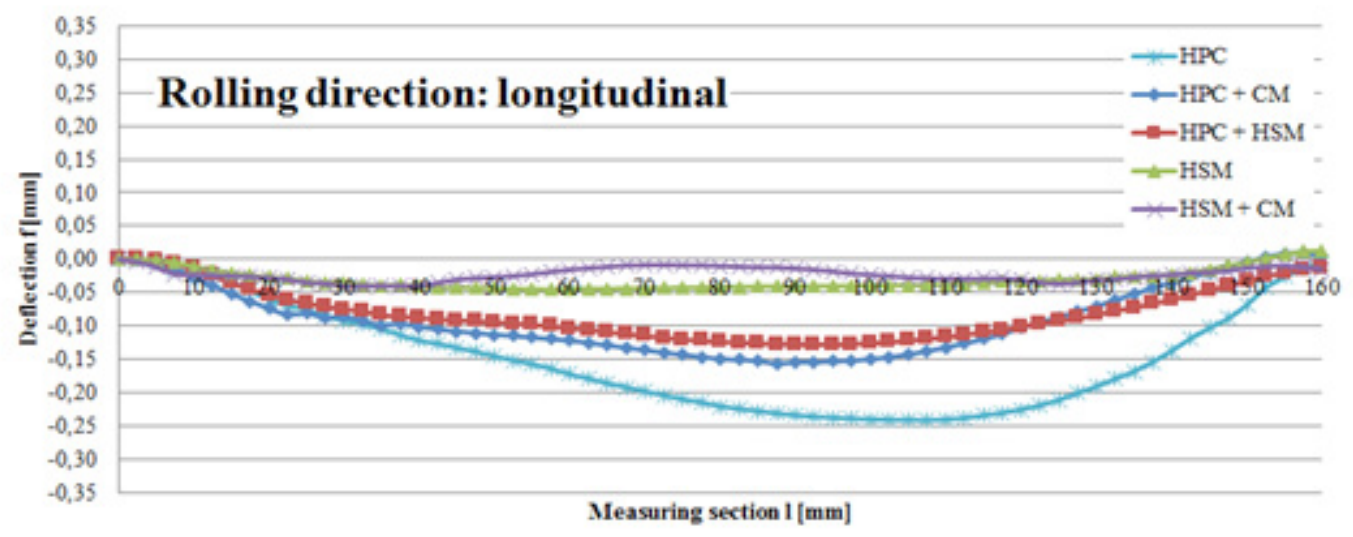

Fig. 6. Test sample deflection $\mathrm{f}$ as a function of measuring section 1 following removal of the fixture forces with the parallel rolling direction and the five analyzed machining strategies 


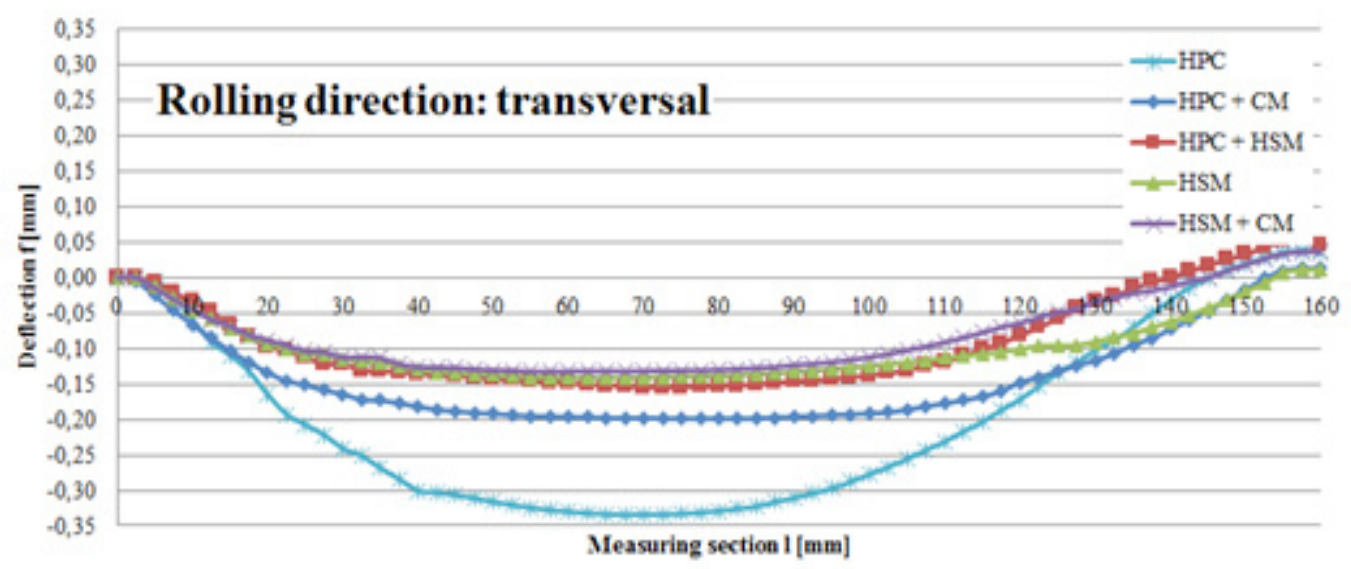

Fig. 7. Test sample deflection $\mathrm{f}$ as a function of measuring section 1 following removal of the fixture forces with the perpendicular rolling direction and the five analyzed machining strategies

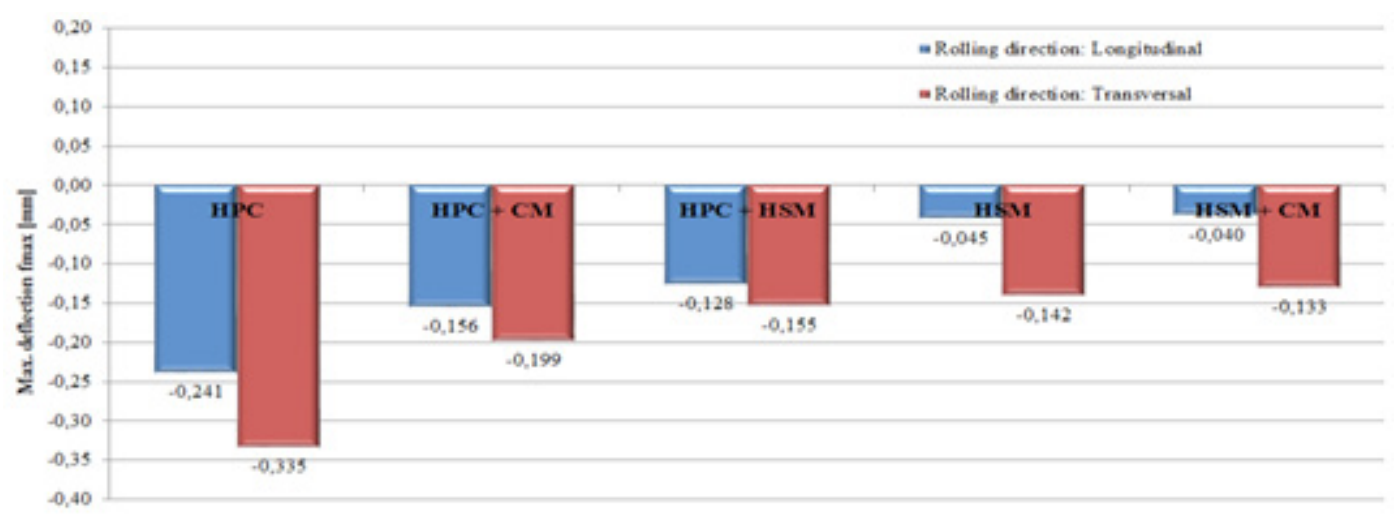

Fig. 8. Summary of the maximum deflections $f_{\max }$ to compare both rolling directions and the studied machining strategies

The deformation measurements were repeated in three iterations across the designated measuring plane.

\section{RESULTS}

The obtained test results were analysed by starting with the effect of the applied machining strategy on the post-machining deformations of the thin-wall elements.

Figure 6 presents the test sample deflection $\mathrm{f}$ as a function of the measuring section 1 following removal of the fixture forces with the longitudinal rolling direction and the five machining strategies investigated. The obtained results revealed that the lowest deformation occurred from High Speed Machining and conventional finish machining, whereas the highest for High Performance Cutting.
A similar comparison of the test sample deflection $\mathrm{f}$ as a function of the measuring section 1 following removal of the fixture forces was developed with the transversal rolling direction, as shown in Figure 7. The lowest deformation levels occurred from High Speed Machining and conventional finish machining, as well as the highest for High Performance Cutting.

Both charts (Figure 6 and Figure 7) present that the deflection had a negative curve, which means that the deviations were below "zero" line.

Figure 8 shows a summary of the maximum deflections $\mathrm{f}_{\max }$ to compare both rolling directions and the studied machining strategies.

This summary (Fig. 8) allowed a conclusion that higher deformation levels were obtained in the transversal rolling direction for each of the studied machining strategies. The High Speed Machining strategy showed deflec- 
tion values negligibly higher than the combination of High Speed Machining and conventional finish machining. However, the differences in deformations between the samples machined with these strategies are insignificant.

\section{CONCLUSION}

The following conclusions can be drawn from the experimental tests discussed in this research work:

- All analysed machining strategies revealed that the deformations were significantly higher in the test samples with the transversal rolling direction.

- The lowest deformation levels both for the test samples with the transversal and longitudinal rolling direction were achieved for the High Speed Machining and conventional finish machining strategy. Insignificantly higher deflections were produced with the High Speed Machining strategy.

The residual stresses residing within the rolled and unmachined surface layer were most likely critical to the value and nature of deformation in the thin-wall elements. Verification tests should be carried out on test samples subject to remove of the textured top layer, produced by plastic working.

Conventional machining can positively contribute to the deformation conditions in machined elements; hence this type of machining can be viable in practice, despite its relatively low efficiency.

\section{Acknowledgements}

Study conducted as part the INNOLOT sector project (Acronym BloStEr) titled "Development of innovative mechanical connections for the purpose of replacing conventional connections in aircraft structures" ("Opracowanie innowacyjnych połączeń mechanicznych celem zastąpienia konwencjonalnych połączeń $\mathrm{w}$ strukturach lotniczych"), coordinated by PZL Mielec Sp. z o.o., subsidised from National Research and Development Centre and European Union funds under the European Regional Development Fund within the scope of the Innovative Economy Operational Programme.Priority I, Action 1.5 IE OP., agreement no. INNOLOT /I/5/NCBR/2013.

\section{REFERENCES}

1. Adamski W.: Manufacturing development strategies in aviation industry. Advances in Manufacturing Science and Technology, 2010, 34, 73-84.

2. Adamski W.: Wybrane kierunki zwiększania wydajności procesów skrawania. Mechanik, 2009, 5-6, 540-546.

3. Amor R.B.: Thermomechanische Wirkmechanizmem und Spanbuldung bei der Hochgeschwindigkeitzerspanung. Universität Hannover, 2003.

4. Andrae P.: Hochleistungszerspanung von Aluminiumknetlegierungen. Universität Hannover, 2002.

5. Burek J., Płodzień M.: Wysoko wydajna obróbka części ze stopów aluminium o złożonych kształtach. Mechanik, 2012, 7, 542-549.

6. Cichosz P.: Obróbka skrawaniem - wysoka produktywność. Oficyna Wydawnicza Politechniki Wrocławskiej, Polska, Wrocław 2007.

7. Deng Y., Duan J.Q., Lu L.Y., Wang Y.J., Xu G.F., Yin Z.M.: Effects of Sc and Zr on the texture and mechanical anisotropy of high strength $\mathrm{Al}-\mathrm{Yn}-\mathrm{Mg}$ alloy sheets. Strength of Materials, 2016, 48, 39-48.

8. Garant Machinin Handbook. Garant, 2010.

9. Kampus Z., Kecelj B., Kopac J., Kuzman K.: Speciality of HSC in manufacturing of forging dies. Journal of Materials Processing Technology, 2004, 157-158, 536-542.

10. Kuczmaszewski J.: Efektywność wytwarzania elementów lotniczych ze stopów aluminium i magnezu. Komputerowo zintegrowane zarządzanie, R. Konsola, Editor, Oficyna Wydawnicza Polskiego Towarzystwa Zarzadzania Produkcja, Opole, 2011, 7-18.

11. Kuczmaszewski J., Pieśko P.: Wear of milling cutters resulting from high silicon aluminium alloy cast AlSi21CuNi machining. Maintenance and Reliability, 2014, 16, 37-41.

12. Kuczmaszewski J., Pieśko P.: Wpływ rodzaju powłok frezów węglikowych na siły skrawania oraz chropowatość powierzchni przy frezowaniu stopu aluminium EN AW-6082. Mechanik, 2013, 10, 846-854.

13. Lahres M., Muller-Hummel P., Doerfel O.: Applicability of different hard coatings in dry milling aluminium alloys. Surface and Coatings Technology, 1997, 91, 161-121.

14. Lopez de Lacallea L.N., Lamikiz A., Sanchez J.A., Arana J.L.: Improving the surface finish in high speed milling of stamping dies. Journal of Materials Processing Technology, 2002, 123, 292-302.

15. Morey B.: High-speed machining for aerospace. Manufacturing Engineering, 2008, 3, 133-143. 
16. Polish Norm: PN-EN 573-3:2014-02. Aluminium and aluminium alloys. Chemical composition and form of wrought products. Part 3: Chemical composition and form of products.

17. Oczoś K.E.: Dobór technik kształtowania ubytkowego wyrobów. Mechanik, 2008, 5-6, 361-379.

18. Oczoś K.E.: Kierunki zwiększania produktywności procesów skrawania. Mechanik, 2007, 5-6, 325-348.

19. Oczoś K.E.: Obróbka wysokowydajna-HPC (High Performance Cutting). Mechanik, 2004, 11, 701-709.

20. Oczoś K.E., Kawalec A.: Kształtowanie metali lekkich. Wydawnictwo Naukowe PWN, Polska, Warszawa 2012.

21. Olszak W.: Obróbka skrawaniem. Wydawnictwa Naukowo-Techniczne, Polska, Warszawa 2009.

22. Pasko R., Przybylski L., Słodki B.: High speed machining (HSM) - the effective way of modern cutting. International Workshop CA Systems And Technologies, 2002, 72-79.

23. Pieśko P., Kłonica M.: Parametry technologiczne obróbki stopów Al i Mg na podstawie analizy literatury i doświadczeń przemysłowych. Workshop - project AERONET: Nowoczesne technologie materiałowe stosowane $\mathrm{w}$ przemyśle lotniczym. Politechnika Warszwska 2009.

24. Sandvik, Die and mould making application guide. Sandvik Coromant, 1999.

25. Tanaka H., Minoda T.: Mechanical properties of 7075 aluminium alloy sheets with fine subgrain structure by warm rolling. Trasaction of Nonferrous Metals Society of China, 2014, 24, 2187-2195.

26. Zhu D., Liu C., Liu Y., Han T., Gao Y., Jiang S.: Evolution of the texture, mechanical properties, and microstructure of $\mathrm{Cu}-2.7$ be alloys during hot cross-rolling. Applied Physics A, 2015, 120, 1605-1613. 